\title{
CALIBRATION AND EVALUATION OF CERES-RICE MODEL UNDER DIFFERENT DENSITY AND WATER MANAGEMENTS
}

\author{
EBRAHIMIRAD, H. $^{1}-$ AMIRI, E. ${ }^{2 *}-$ BABAZADEH, H. ${ }^{1}-$ SEDGHI, H. ${ }^{1}$ \\ ${ }^{I}$ Department of Water Science and Engineering, Science and Research Branch, Islamic Azad \\ University, Tehran, Iran \\ (phone: +98-911-337-7497-H. E. R., +98-912-699-0105-H. B., +98-912-348-6557-H. S.) \\ ${ }^{2}$ Department of Water Engineering, Lahijan Branch, Islamic Azad University, Lahijan, Iran \\ (phone: +98-911-651-6300) \\ *Corresponding author \\ e-mail: eamiri57@yahoo.com; phone: +98-911-651-6300 \\ (Received $13^{\text {th }}$ Jun 2018; accepted $2^{\text {nd }}$ Aug 2018)
}

\begin{abstract}
The objective of this study was the evaluation of the Ceres-Rice model under different density and water management options in Semi-Mediterranean climate condition. An experiment was conducted in a randomized complete block design (RCBD) with three replications in north of Iran during cropping seasons of 2014 and 2015. There were 5 levels of irrigation treatments in this research including: $\mathrm{I}_{1}$ : Flood irrigation, $\mathrm{I}_{2}$ : Saturation, $\mathrm{I}_{3}$ : Irrigation with 8 days alternative before anthesis, $\mathrm{I}_{4}$ : Irrigation with 8 days alternative after anthesis, $\mathrm{I}_{5}$ : Irrigation with 8 days alternative whole growth season) and there were three plant spacing including: $\mathrm{D}_{1}=15 \times 15, \mathrm{D}_{2}=20 \times 20, \mathrm{D}_{3}=25 \times 25 \mathrm{~cm}$. Evaluation simulated and measured grain yield, total crop biomass, and crop biomass by adjusted coefficient of correlation and by absolute and normalized root mean square errors (RMSE). Grain yield of $\mathrm{D}_{2}$ was predicted the most accurate than other density treatments $(\mathrm{RMSE}=439$ and RMSEn $=11 \%)$. Biomass of $\mathrm{D}_{2}$ was predicted the most accurate than other density treatments (RMSE $=873$ and RMSEn $=9 \%$ ). Observed and predicted planting densities by rice showed good agreement in both calibration and evaluation steps. The Ceres-Rice model can be applied to research purposes (irrigation and planting densities) under northern Iranian conditions.
\end{abstract}

Keywords: Semi-Mediterranean, Ceres-Rice, Irrigation, Crop Model, Water Productivity

\section{Introduction}

Rice is a main food for majority of the world's population, raised on about 146.5 million ha of the agricultural fields of the world. So it is necessary to optimize usage of available resources due to shortage of water resources in rice fields (Thakur et al., 2014; Gill et al., 2014; Murumkar et al., 2014). Water necessity is more for this plant than other grains and the amount of it is affected by the rice cultivar, stage of growth, length of growth stage, plant density and even method of cultivation and weather conditions. Iran is an area with an annual rainfall of $240 \mathrm{~mm}$ and 0.57 million ha paddy field. Most rainfalls occur out of rice growth stages. Water allocation is not sufficient for low efficient irrigation in Iran, and surface water storage will be increased by construction of dams (Amiri et al., 2011).

Agricultural water productivity directly affects crop production; therefore, various water saving techniques and managements have been developed for rice producers to minimize water use and maintain optimum yield (Pascual, 2016). For instance, observed yield and simulated water balance, the calculated average $\mathrm{WP}_{\mathrm{ET}}$ was significantly lower than the average $\mathrm{WP}_{\mathrm{T}}$ : $37 \%$. The average $\mathrm{WP}_{\mathrm{I}}, \mathrm{WP}_{\mathrm{ET}}$, $\mathrm{WP}_{\mathrm{T}}$ and $\mathrm{WP}_{\mathrm{ETQ}}$ were $1.01,0.89$, 1.41 and $0.65 \mathrm{kgm}^{-3}$ (Amiri and Rezaei, 2013). 
Severe drought stress at mid-tillering delayed flowering, and caused substantial yield losses by large percentage of unfilled grains (Davatgar et al., 2009). This finding has been confirmed by Pirdashti et al. (2009) who pointed out that water shortage in the vegetative growth stage extended the number of days for flowering in different rice cultivars. It has been documented that dry matter is more affected under vegetative stage stress whereas severe effects on sink size (spikelet fertility, 1000 grain weight and seed yield) under reproductive stage stress would be resulted (Guan et al., 2010).

Roderick et al. (2011) concluded in a research that alternate wet and drying irrigation deficit method has reduced about $38 \%$ of irrigation water usage, with the same yields and farmers profits.

High densities of rice cultivation reduce plant yield and yield components (Chamara et al., 2016). Some researchers have reported increased yield per unit area as a result of increasing density per unit area (Clerget et al., 2016). Other researchers have also reported declined yield and biomass per unit area due to increasing density (Awan et al., 2014). In addition, high densities are recommended to suppress weeds and increase yield in rice (Chauhan et al., 2011).

In order to detect the effect of planting density on the water productivity of rice product, an experiment was conducted in a split plot design with three plant-distance $(20 \times 20,15 \times 15,20 \times 10 \mathrm{~cm})$ as a sub plots and four different irrigation regimes (permanent flooding treatment as a control group and 100\%, 75\% and 50\% evaporation from the pan) as the main factors. The best yield in irrigation was reported for $75 \%$ evaporation from the pan and the plant-density of $(20 \times 20 \mathrm{~cm})$ (Amiri et al., 2011).

In recent years, there has been an increasing amount of literature on simulation and modeling application on rice production (Amiri et al., 2014; Vijayalaxmi et al., 2016)

Until now, the most conducted researches have been about the method of irrigation management based on fixed round of irrigation from the first to the end of growing season. Fewer researches have been conducted about the method of irrigation management regarding cultivation density. At present, information required for the rice production improvement with suitable management practices is a need of hour. The generation of new data through agronomic research methods is insufficient and time consuming to meet these needs. So crop simulation models are considered as potentially useful tools in agricultural decision making. The major objectives of this study were to investigate: (i) Modeling response of Hashemi rice variety to change in planting densities and irrigation managements (ii) Calibrate and validate the DSSAT v 4.5. model based on experimental data; (iii) To explore on-farm strategies which result in higher economic gains and water productivity.

\section{Materials and methods}

\section{Experimental design, crop establishment, and crop management}

The experiment was conducted as split plot based on randomized complete block design with three replications on rice Hashemi cultivar during growing season of 2014 and 2015 in Koosal-Lahijan region located in north of Iran. The height of the site is $3 \mathrm{~m}$ from the sea level and it is located at $14^{\prime \prime} 3{ }^{\prime} 37^{\circ}$ of north latitude and14" 1 ' $50^{\circ}$ of east length. Irrigation treatments were at five levels: full irrigation $=I_{1}$ saturated $=I_{2}$ irrigation with 8 days alternative until anthesis $=I_{3}$, irrigation with 8 days alternative after anthesis $=\mathrm{I}_{4}$, irrigation with 8 days alternative during the whole period of growth $=\mathrm{I}_{5}$ and density was at 3 levels: $15 \times 15=\mathrm{D}_{1}, 20 \times 20=\mathrm{D}_{2}, 25 \times 25=\mathrm{D}_{3} \mathrm{~cm}$ 
(444000, 250000, 160000 plants per hectare, respectively). Each experimental plot was $9.2 \mathrm{~m}$ long and $3 \mathrm{~m}$ wide. After transplanting the markers to the main land, the plots were kept for 10 days in permanent flooding until the markers were settled. After that, irrigation management was applied in the plots based on the program. $\mathrm{I}_{1}$ was often flooding and $\mathrm{I}_{2}$ was often saturated. $\mathrm{I}_{3}$ was irrigated every 8 days before anthesis and then was flooded. The treatments $\mathrm{I}_{4}$ was irrigated every two to three days before anthesis and then irrigated every 8 days. $\mathrm{I}_{5}$ was completely irrigated every 8 days. It should be noted that the management of irrigation with frequency of 8 days (Amiri and Rezaei, 2013) was performed based on the alternation according to the growth of rice, using optimal water management in drought stress condition and in order to cope with damages caused by water stress on Hashemi cultivar.

According to the Table 1, soil of the experiment site is suitable for rice. Table 2 also shows crop information and Figures 1 and 2 shows the meteorological characteristics of the site. The first 20 days were irrigated by flooding. Urea, potassium and phosphate fertilizers were each used at baseline of $60 \mathrm{~kg} \cdot \mathrm{ha}^{-1} .60 \mathrm{~kg}$ urea fertilizer was also consumed one month after the baseline stage. Graining was carried out at the end of April in the treasury environment and transplantation of the treatments was done at the end of May. After handling and harvesting, the clusters were placed in an oven for drying for $72 \mathrm{~h}$ at $70{ }^{\circ} \mathrm{C}$.

Table 1. Soil physical and chemical characteristics of the experimental site before sowing the rice crop

\begin{tabular}{c|c|c|c|c|c}
\hline \multirow{2}{*}{ Soil characteristics } & \multicolumn{4}{|c|}{ Depth (cm) } & \multirow{2}{*}{$\mathbf{4 0 - 5 0}$} \\
\cline { 2 - 5 } & $\mathbf{0 - 1 0}$ & $\mathbf{1 0 - 2 0}$ & $\mathbf{2 0}-\mathbf{3 0}$ & $\mathbf{3 0}-\mathbf{4 0}$ & \\
\hline Texture & & & & & \\
Sand (\%) & 18 & 14 & 17 & 9 & 11 \\
Silt (\%) & 39 & 39 & 39 & 44 & 42 \\
Clay (\%) & 47 & 47 & 44 & 47 & 47 \\
Bulk density (g cm $\left.{ }^{-3}\right)$ & 1.45 & 1.4 & 1.4 & 1.42 & 1.41 \\
Water content at saturation & 0.392 & 0.392 & 0.39 & 0.39 & 0.39 \\
Water content at FC $(0.01 \mathrm{MPa})$ & 0.204 & 0.204 & 0.209 & 0.209 & 0.209 \\
Water content at PWP $(1.5 \mathrm{MPa})$ & 0.34 & 0.34 & 0.345 & 0.345 & 0.345 \\
KSAT (cm day $\left.{ }^{-1}\right)$ & 57.54 & 57.54 & 30.79 & 0.40 & 11.79 \\
pH & 7.05 & 7.15 & 7.23 & 7.26 & 7.08 \\
CEC (meq 100 g $\left.{ }^{-1}\right)$ & 33 & 33 & 32 & 31 & 31 \\
Organic carbon (\%) & 2.30 & 2.72 & 2.54 & 2.25 & 2.76 \\
Total N (\%) & 0.19 & 0.16 & 0.14 & 0.074 & 0.074 \\
Extractable P (ppm) & 8.7 & 10.1 & 7.3 & 5.2 & 3.2 \\
Extractable K (ppm) & 225 & 195 & 176 & 185 & 161 \\
\hline
\end{tabular}

Table 2. Crop information in two different years of experiment

\begin{tabular}{c|c|c|c|c|c|c|c|c}
\hline $\begin{array}{c}\text { Crop } \\
\text { year }\end{array}$ & $\begin{array}{c}\text { Date of } \\
\text { plowing }\end{array}$ & $\begin{array}{c}\text { Date of } \\
\text { plotting }\end{array}$ & $\begin{array}{c}\text { Date of } \\
\text { fertilizing }\end{array}$ & $\begin{array}{c}\text { Date of } \\
\text { transplantation }\end{array}$ & $\begin{array}{c}\text { Date of } \\
\text { anthesis }\end{array}$ & $\begin{array}{c}\text { Date of } \\
\text { excess } \\
\text { fertilizing }\end{array}$ & $\begin{array}{c}\text { Date of } \\
\text { harvesting }\end{array}$ & $\begin{array}{c}\text { Total } \\
\text { period of } \\
\text { growth-day }\end{array}$ \\
\hline 2014 & 27 May & 30 May & 4 Jun. & 2 Jun. & 5 Aug. & 6 Jul. & 5 Sep. & 95 \\
2015 & 27 May & 31 May & 4 Jun. & 3 Jun. & 6 Aug. & 6 Jul. & 10 Sep. & 99 \\
\hline
\end{tabular}




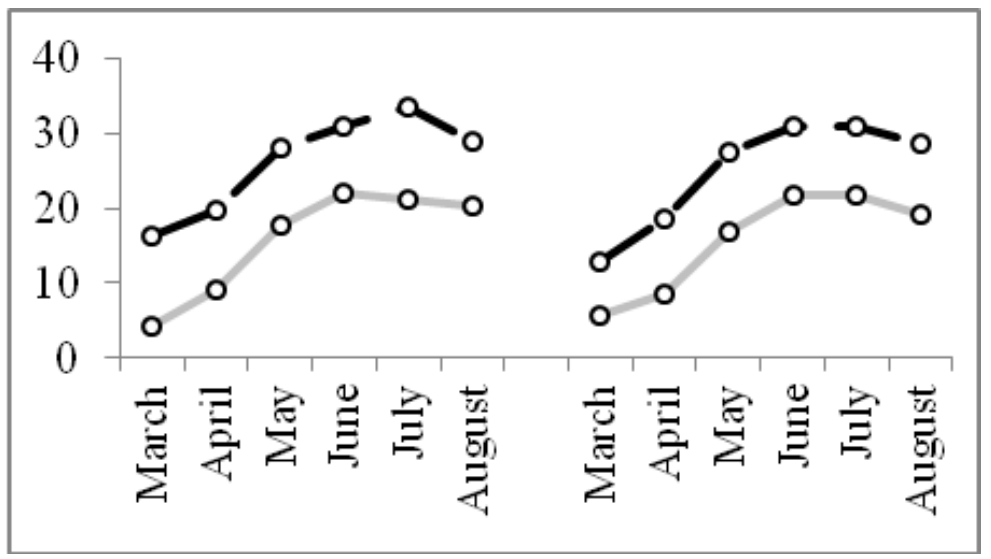

Figure 1. Monthly minimum and maximum air temperatures $\left({ }^{\circ} \mathrm{C}\right)$ during the growing periods of rice in 2014 and 2015 growing seasons (left to right, respectively)

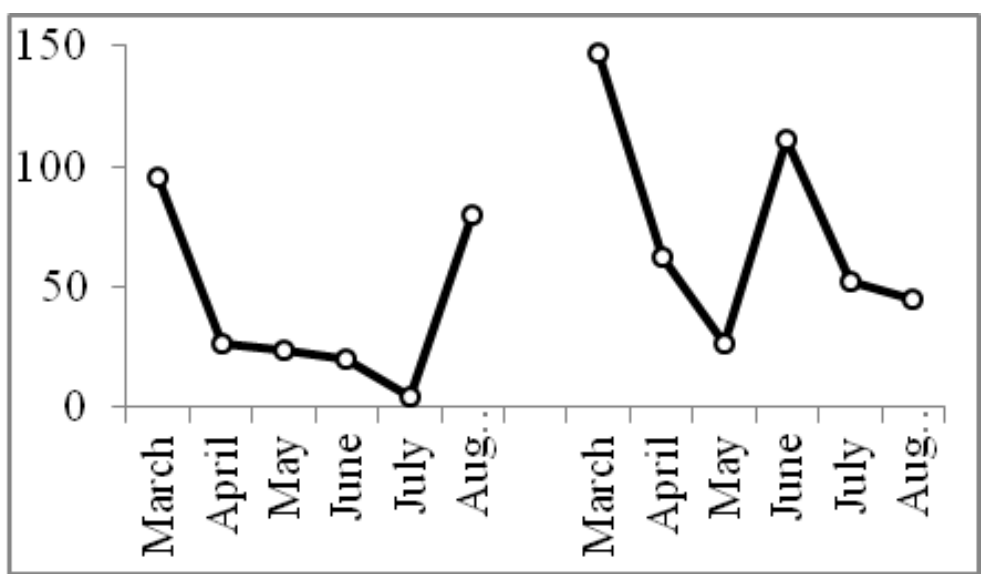

Figure 2. Monthly rainfall during the growing periods of rice in 2014 and 2015 growing seasons (left to right, respectively)

\section{Ceres-Rice description}

Ceres-Rice model was selected as a tool for simulating growth and yield of rice under different environment and management strategies. The Ceres-Rice model simulates rice crop growth and development from either planting or transplanting to physiological maturity and is based on the physiological processes that describe the response of rice to local soil and weather conditions. Potential growth is mainly dependent upon photosynthetically active radiation (PAR), light interception and the light conversion efficiency, while actual growth is a constraint of crop management, soil and weather interactions.

The input data required to run the DSSAT models include daily weather data, i.e. maximum and minimum temperature, rainfall, and solar radiation; soil characterization data, genetic coefficients and crop management information, such as date of planting, age of seedlings, row and plant spacing, rates and dates and amount of fertilizer and irrigation applied. Input data files of Ceres-Rice model are as per IBSNAT standard input/output formats and file structure described in DSSAT v 4.5 (Hoogenboom et al., 2003). 


\section{Model inputs}

The DSSAT models require the minimum data set for model operation. They encompass data on the site where the model is to be operated, on the daily weather data, on the soil properties, and on the all aspects management of the crop growth. Important crop management factors include planting date, planting depth, row spacing and direction, plant population, fertilization, irrigation, inoculation, residue applications, tillage, and harvest date.

\section{Calibration of Ceres-Rice model}

The calibration of the Ceres-Rice model was based on data from measured data of grain yield, total biomass in 2014-2015 field experiment. The genetic coefficients of the rice cv. Hashemi that affect the occurrence of phonological stages in the Ceres-Rice models were derived using the GLUE Estimator of DSSAT v 4.6. This program estimates the coefficients for a genotype by iteratively running the crop model with an approximate value of the coefficients concerned.

One would expect to have, for good model performance, values of RMSE as close as possible to 0 . A model produces experimental data perfectly when $\alpha$ is close to $1, \beta$ is close to $0, R^{2}$ is close to 1 , RMSEa is similar to the SD of measured values, and RMSEn is similar to the coefficient of variation $(\mathrm{CV})$ of measured values.

\section{Model evaluation}

Summary measures used in the present study were the mean of measured and simulated values, the standard deviations (SD) of the observations and simulations, the slope $\alpha$, intercept $\beta$, and coefficient of determination $\left(\mathrm{R}^{2}\right)$ of the linear regression line between simulated and measured values. The different measures were based on the analysis of residual errors, that is, the difference between simulated and measured values. We computed the absolute and normalized root mean square errors (RMSE and RMSEn, respectively). Also, based on the measured data and relationship data and statistical estimation of the model were done through the root mean square error (RMSE), normalized root mean square error (RMSEn), relative error of the model (ME). When the RMSE and RMSEn values are closer to zero, it indicates that the prediction has been done better by relations (Eqs. 1-3).

$$
\begin{gathered}
R M S E=\sqrt{\frac{\sum_{i=1}^{n}\left(P_{i}-O_{i}\right)^{2}}{n}} \\
\left.R M S E_{n}=100\left(\sum_{i=1}^{n}\left(P_{i}-O_{i}\right)^{2} / n\right)^{0.5}\right) / \bar{O} \\
R M S E=100\left(\frac{P_{i}-O_{i}}{O_{i}}\right)
\end{gathered}
$$

In the first two relations (Eq. 1 and 2), $\mathrm{S}_{\mathrm{i}}$ and $\mathrm{O}_{\mathrm{i}}$ are respectively the values of relative and observed performance equations. $\bar{O}$ is the mean of observed values and $\mathrm{n}$ is the number of observations (Amiri et al., 2011). 


\section{Water balance components}

The water balance of lowland rice model includes (Eq. 4):

$$
d W=I+R+C-E-T-S-Q-D
$$

where $\mathrm{dW}$ is the change in stored water, $\mathrm{I}$ is irrigation supply, $\mathrm{R}$ is rainfall, $\mathrm{C}$ is capillary rise, $\mathrm{E}$ is evaporation, $\mathrm{T}$ is transpiration, $\mathrm{S}$ is seepage, $\mathrm{Q}$ is percolation, and $\mathrm{D}$ is surface drainage/runoff (all units are $\mathrm{mm}$ ) (Bouman et al., 2001).

\section{Water productivity}

WP indices express the profit derived from the consumption of water and can be used for assessing the impact of on-farm strategies under water scarce situations. They provide a proper vision of where and when water could be conserved. The following equations (Eqs. 5-9) were used to calculate the water productivity components (Singh et al., 2006).

$$
\begin{gathered}
W P_{T}=\frac{Y_{g}}{T} \\
W P_{E T}=\frac{Y_{g}}{E+T} \\
W P_{I}=\frac{Y_{g}}{I} \\
W P_{I+R}=\frac{Y_{g}}{I+R} \\
W P_{E T Q}=\frac{Y_{g}}{E+T+Q}
\end{gathered}
$$

where $\mathrm{Yg}(\mathrm{Kg})$ is the crop grain yield, $\mathrm{T}(\mathrm{mm})$ is the actual transpiration, $\mathrm{E}(\mathrm{mm})$ is the actual soil evaporation, $I(\mathrm{~mm})$ is irrigation, $\mathrm{R}(\mathrm{mm})$ is rainfall and $\mathrm{Q}(\mathrm{mm})$ is the percolation. $\mathrm{WP}_{\mathrm{I}}\left(\mathrm{kg} / \mathrm{m}^{3}\right), \mathrm{WP}_{\mathrm{I}+\mathrm{R}}\left(\mathrm{kg} / \mathrm{m}^{3}\right), \mathrm{WP}_{\mathrm{ET}}\left(\mathrm{kg} / \mathrm{m}^{3}\right), \mathrm{WP}_{\mathrm{T}}\left(\mathrm{kg} / \mathrm{m}^{3}\right)$ and $\mathrm{WP}_{\mathrm{ETQ}}$ $\left(\mathrm{kg} / \mathrm{m}^{3}\right)$ are expressed in crop grain yield $(\mathrm{Yg})$ per unit amount of I, I+R, ET, T and ETQ respectively.

\section{Results and discussion}

\section{Model calibration}

The calibrated genetic coefficients (cv. Hashemi) as derived by Gencalc for CeresRice are given in Table 3.

Table 4 shows the goodness-of-fit parameters for grain yield and aboveground biomass at harvest of the whole data set. The model simulated aboveground biomass 
and Grain yield quite well, with the absolute and normalized RMSE values greater than the error in the measured value (Table 4). For biomass, the slope was close to 1, and the intercept $\beta$ was high, indicating general overestimation of simulated values. Almost the same pattern was observed for grain yield. The model simulated grain yield and biomass generally good. The slope in validation was a little bit greater than that of calibration while the intercept $\beta$ was less than that of calibration. The relatively high $\mathrm{R}^{2}$ reflects the low spread of the data. The error value in validation step has decreased, which is a reason to accept the results of the model. Also, the mean square error should be less than the standard deviation of the actual values that the results of the evaluation of Ceres-Rice model accuracy in irrigation management and different crop distances indicate that.

Table 3. Genetic coefficients of the rice cv. Hashemi as derived by GENCALC of DSSAT model

\begin{tabular}{|c|c|c|}
\hline $\begin{array}{c}\text { Genetic } \\
\text { parameters }\end{array}$ & Description & $\begin{array}{l}\text { Coefficient for } \\
\text { Hashemi }\end{array}$ \\
\hline P1 & $\begin{array}{l}\text { Time period (expressed as growing degree days (GDD) in }{ }^{\circ} \mathrm{C} \text { above a } \\
\text { base temperature of } 9^{\circ} \mathrm{C} \text { from seedling emergence during which the } \\
\text { rice plant is not responsive to changes in photoperiod }\end{array}$ & 320.0 \\
\hline $\mathrm{P} 20$ & $\begin{array}{l}\text { Critical photoperiod or the longest day length (in } \mathrm{h} \text { ) at which the } \\
\text { development occurs at a maximum rate }\end{array}$ & 5.0 \\
\hline $\mathrm{P} 2 \mathrm{R}$ & $\begin{array}{l}\text { Extent to which phasic development leading to panicle initiation is } \\
\text { delayed (expressed as GDD in }{ }^{\circ} \mathrm{C} \text { ) for each hour increase in } \\
\text { photoperiod above P20 }\end{array}$ & 13.5 \\
\hline P5 & $\begin{array}{l}\text { Time period in GDD }{ }^{\circ} \mathrm{C} \text { ) from beginning of grain filling ( } 3 \text { to } 4 \text { days } \\
\text { after flowering) to physiological maturity with a base temperature of } \\
\qquad 9^{\circ} \mathrm{C}\end{array}$ & 240.0 \\
\hline G1 & $\begin{array}{l}\text { Potential spikelet number coefficient as estimated from the number of } \\
\text { spikelets per g of main culm dry weight (less lead blades and sheaths } \\
\text { plus spikes) at anthesis }\end{array}$ & 55.2 \\
\hline G2 & $\begin{array}{c}\text { Single grain weight }(\mathrm{g}) \text { under ideal growing conditions, i.e., } \\
\text { nonlimiting light, water, and nutrients and absence of pests and diseases }\end{array}$ & 0.0200 \\
\hline G3 & $\begin{array}{c}\text { Tillering coefficient (scaler value) relative to IR64 cultivar under ideal } \\
\text { conditions }\end{array}$ & 1.00 \\
\hline G4 & $\begin{array}{l}\text { Temperature tolerance coefficient. Usually } 1.0 \text { for varieties grown in } \\
\text { normal environments }\end{array}$ & 1.00 \\
\hline
\end{tabular}

\section{Model evaluation}

Grain yield the graphical comparison between simulated and measured grain yield is presented in Figure 3. The Ceres-Rice model simulated grain yield in 2015 quite well. Grain yield of $\mathrm{D}_{2}$ was predicted the most accurate than other density treatments $\left(\mathrm{R}^{2}=0.85\right)$.

The graphical performance of the Ceres-Rice model in simulating total crop biomass at harvest is presented in Figure 4. Similar to the simulation results of the grain yield, the best performance of the model in simulating total crop biomass was obtained in 
2015. Biomass of $\mathrm{D}_{2}$ was predicted the most accurate than other density treatments $\left(\mathrm{R}^{2}=0.89\right)$.

Table 4. Evaluation results for Ceres-Rice simulations of final aboveground biomass and yield, for the calibration and validation conditions

\begin{tabular}{|c|c|c|c|c|c|c|c|c|c|c|c|}
\hline Year & Crol & variables & $\mathbf{N}$ & $\mathbf{X}_{\text {obs }}$ & $\mathbf{X}_{\text {sim }}$ & $\mathbf{S d}_{\mathrm{obs}}$ & $\alpha$ & B & $\mathbf{R}^{2}$ & $\begin{array}{c}\text { RMSE } \\
\left.\text { (kg.ha }^{1}\right)\end{array}$ & $\begin{array}{c}\text { RMSEn } \\
(\%)\end{array}$ \\
\hline \multirow{6}{*}{ 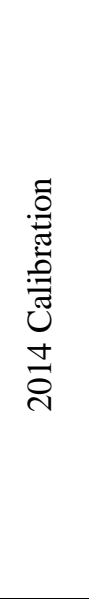 } & \multirow{2}{*}{$\mathrm{D}_{1}$} & $\begin{array}{l}\text { Biomass } \\
\left(\mathrm{kg} \mathrm{ha}^{-1}\right)\end{array}$ & 5 & 9648 & 10027 & 2254 & 0.40 & 6168 & 0.72 & 1363 & 14.13 \\
\hline & & $\begin{array}{c}\text { Yield } \\
\left(\mathrm{kg}^{\left.-\mathrm{ha}^{-1}\right)}\right.\end{array}$ & 5 & 3736 & 4042 & 919 & 0.79 & 1093 & 0.78 & 491 & 13.15 \\
\hline & \multirow{2}{*}{$\mathrm{D}_{2}$} & $\begin{array}{l}\text { Biomass } \\
\left(\mathrm{kg} \cdot \mathrm{ha}^{-1}\right)\end{array}$ & 5 & 9944 & 9930 & 2069 & 052 & 4719 & 0.87 & 955 & 9.60 \\
\hline & & $\begin{array}{c}\text { Yield } \\
\left(\mathrm{kg} \cdot \mathrm{ha}^{-1}\right)\end{array}$ & 5 & 3818 & 3971 & 1212 & 070. & 1314 & 0.83 & 499 & 13.06 \\
\hline & \multirow{2}{*}{$\mathrm{D}_{3}$} & $\begin{array}{l}\text { Biomass } \\
\left(\mathrm{kg}^{\prime} \mathrm{ha}^{-1}\right)\end{array}$ & 5 & 9379 & 9720 & 1449 & 0.54 & 4682 & 0.57 & 917 & 9.78 \\
\hline & & $\begin{array}{c}\text { Yield } \\
\left(\mathrm{kg}^{\left.-\mathrm{ha}^{-1}\right)}\right.\end{array}$ & 5 & 3741 & 3907 & 874 & 0.77 & 1045 & 0.63 & 521 & 13.92 \\
\hline \multirow{6}{*}{ 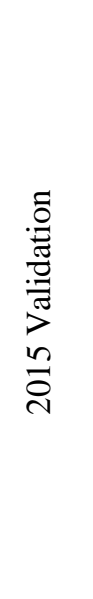 } & \multirow{2}{*}{$\mathrm{D}_{1}$} & $\begin{array}{l}\text { Biomass } \\
\left(\mathrm{kg} \cdot \mathrm{ha}^{-1}\right)\end{array}$ & 5 & 9093 & 9638 & 1678 & 0.58 & 4364 & 0.77 & 958 & 10.53 \\
\hline & & $\begin{array}{c}\text { Yield } \\
\left(\mathrm{kg}^{\left.-\mathrm{h}^{-1}\right)}\right.\end{array}$ & 5 & 3837 & 4188 & 814 & 0.81 & 1082 & 0.81 & 473 & 12.32 \\
\hline & \multirow{2}{*}{$\mathrm{D}_{2}$} & $\begin{array}{l}\text { Biomass } \\
\left(\mathrm{kg} \cdot \mathrm{ha}^{-1}\right)\end{array}$ & 5 & 9858 & 9563 & 1783 & 0.59 & 3750 & 0.89 & 790 & 8.02 \\
\hline & & $\begin{array}{c}\text { Yield } \\
\left(\mathrm{kg}^{-h^{-1}}\right)\end{array}$ & 5 & 3926 & 4095 & 937 & 0.74 & 1191 & 0.85 & 379 & 9.66 \\
\hline & \multirow{2}{*}{$\mathrm{D}_{3}$} & $\begin{array}{l}\text { Biomass } \\
\left(\mathrm{kg}^{\prime} \mathrm{ha}^{-1}\right)\end{array}$ & 5 & 9269 & 9343 & 1098 & 0.55 & 4231 & 0.64 & 872 & 9.41 \\
\hline & & $\begin{array}{c}\text { Yield } \\
\left(\mathrm{kg}^{\left.-\mathrm{ha}^{-1}\right)}\right.\end{array}$ & 5 & 3842 & 4000 & 852 & 0.76 & 1073 & 0.69 & 457 & 11.90 \\
\hline
\end{tabular}

$\mathrm{N}$ : number of treatments, $\mathrm{X}_{\text {obs: }}$ : mean of observed value; $\mathrm{X}_{\text {sim }}$ : mean of simulated value; $\mathrm{Sd}_{\text {obs }}$ : standard deviation of observed value; $\alpha$ : slope of linear relation between simulated and measured values; $\beta$ : intercept of linear relation between simulated and measured values; $\mathrm{R}^{2}$ : adjusted linear correlation coefficient between simulated and measured values; RMSEn: normalized root mean square error (\%); RMSE: absolute, absolute root mean square error

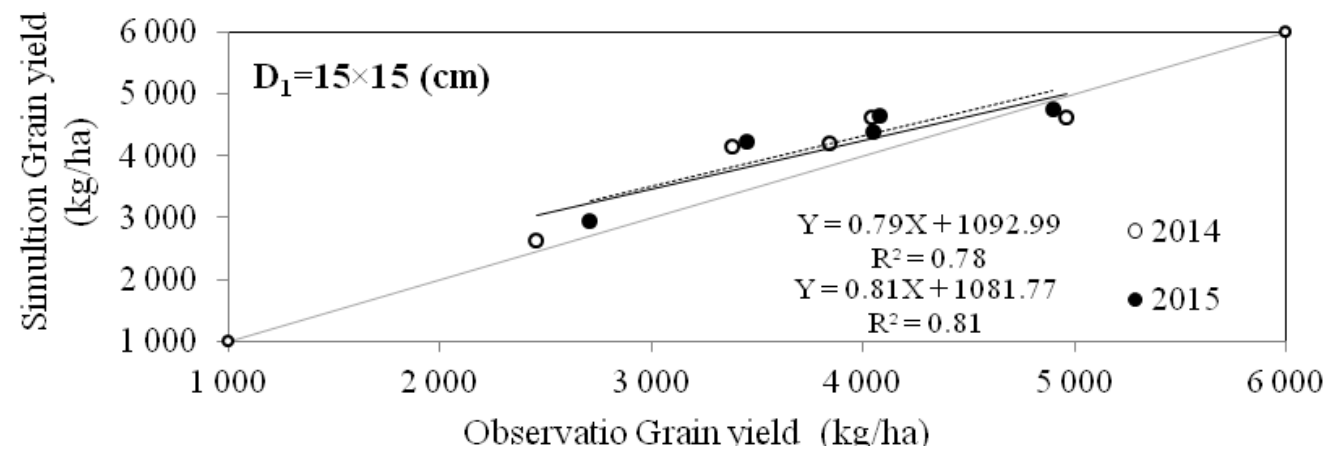




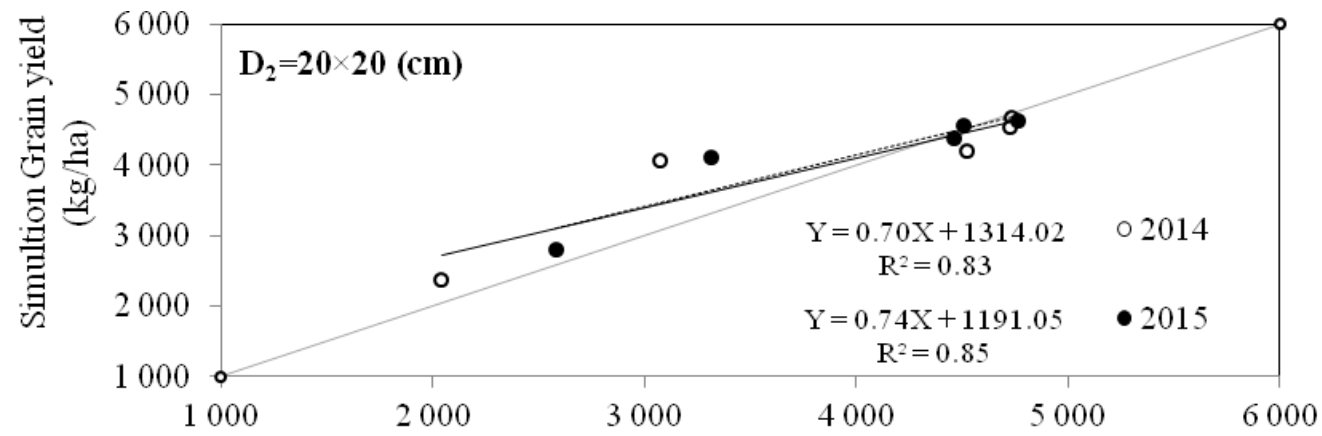

Observatio Grain yield $(\mathrm{kg} / \mathrm{ha})$

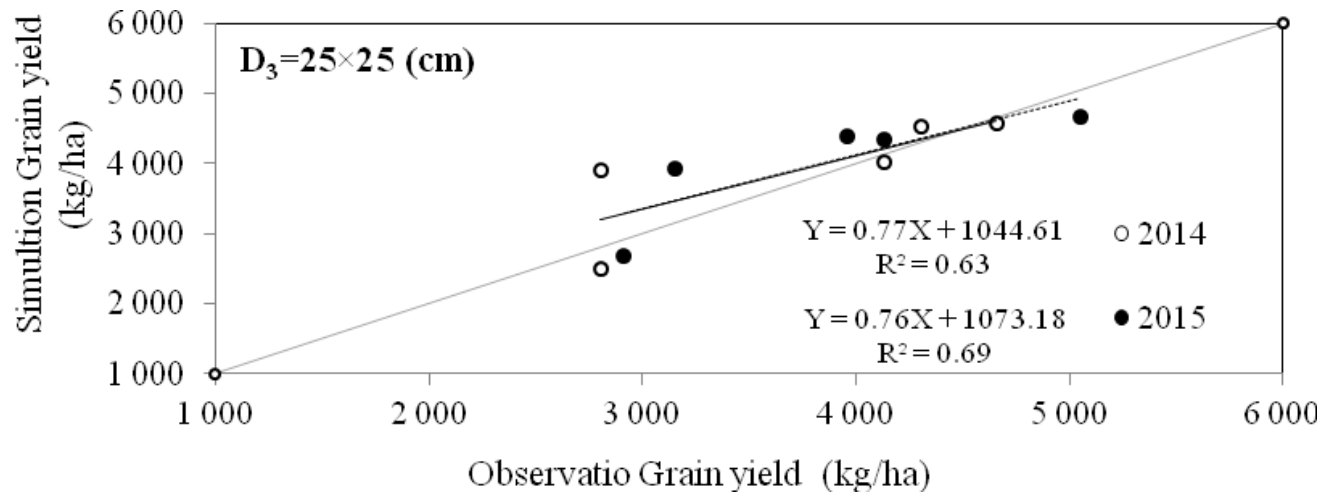

Figure 3. Evaluation of Ceres-Rice model for grain yield under different density and water management
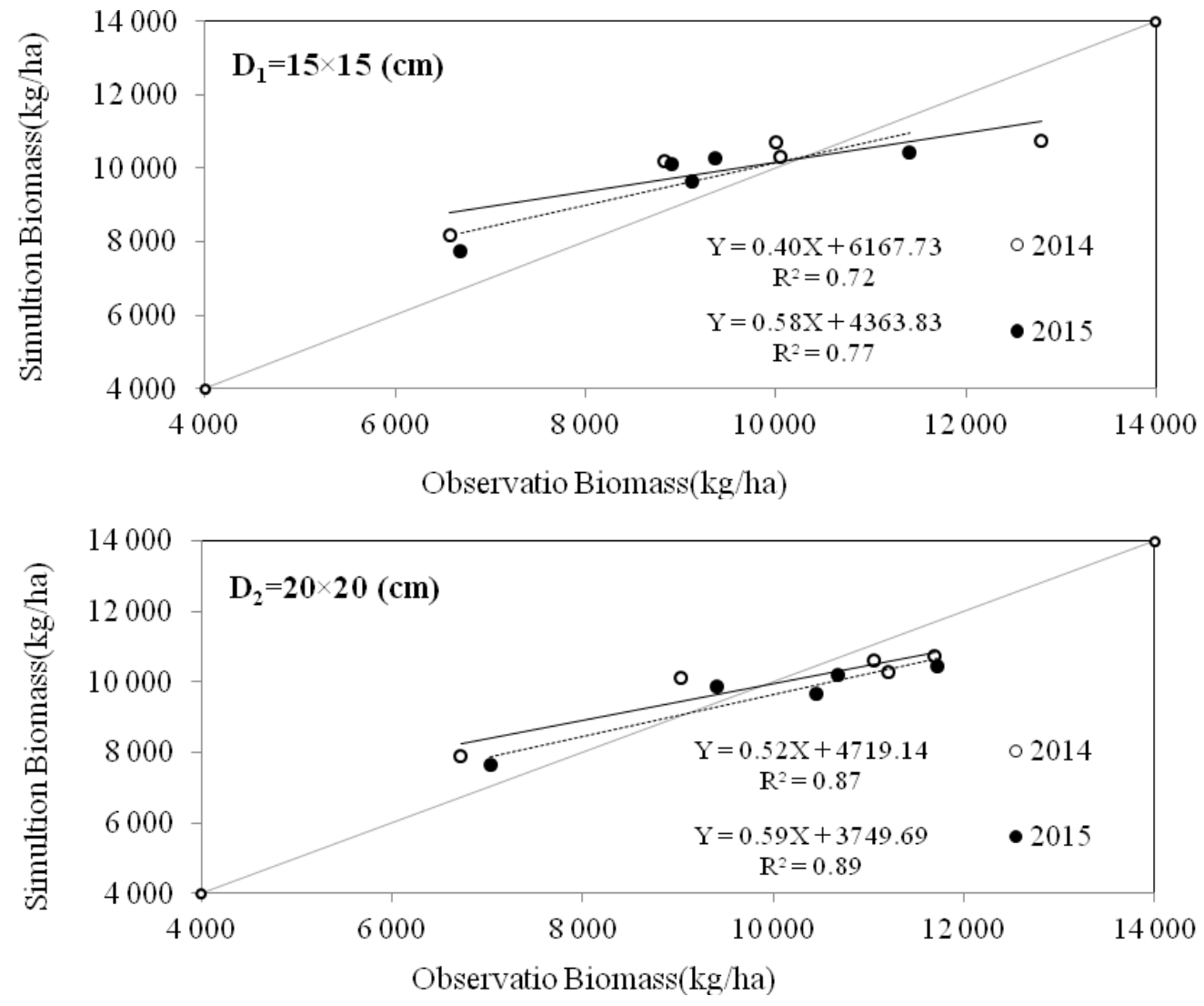

APPLIED ECOLOGY AND ENVIRONMENTAL RESEARCH 16(5):6469-6482 http://www.aloki.hu • ISSN 15891623 (Print) • ISSN 17850037 (Online) DOI: http://dx.doi.org/10.15666/aeer/1605_64696482 (c) 2018, ALÖKI Kft., Budapest, Hungary 


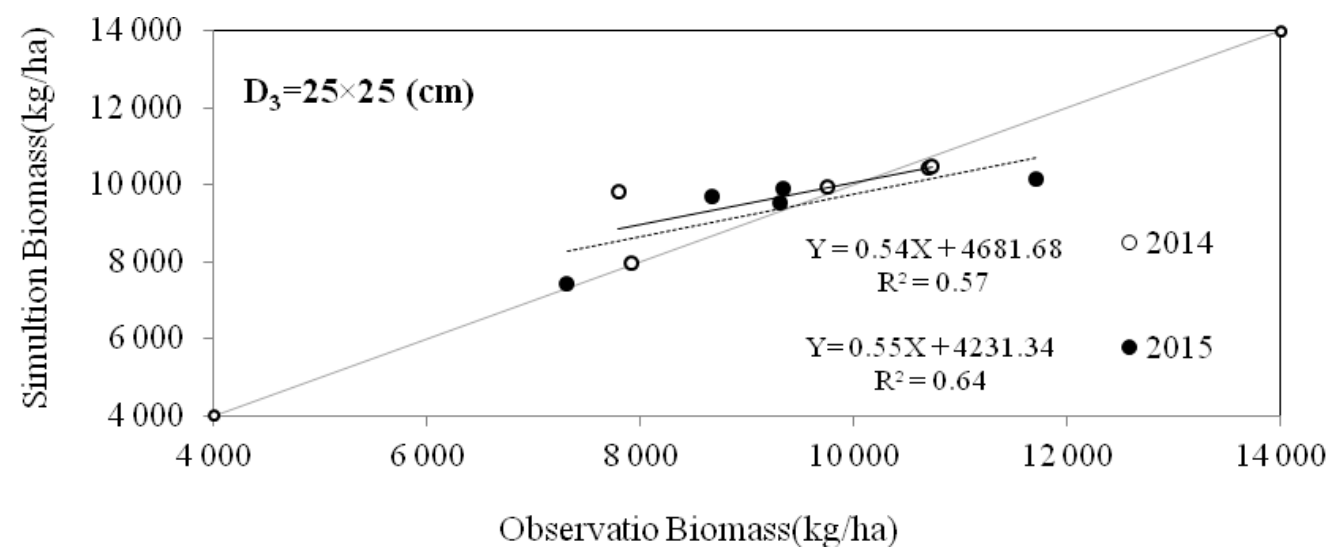

Figure 4. Evaluation of Ceres-Rice model for final above ground biomass under different density and water management

The use of Ceres-Rice model in different years to simulate rice yield in irrigation management and different densities is shown in Figure 5. The ability of the Ceres-Rice model to simulate the total biomass of rice in different years under irrigation management and different densities is shown in Figure 6. In the second year, the plant was exposed to warmer days and the rice plant was subjected to more severe drought stress, which caused the plant to close its stomata more than the first year, and the yield and total biomass decreased compared to the first year.
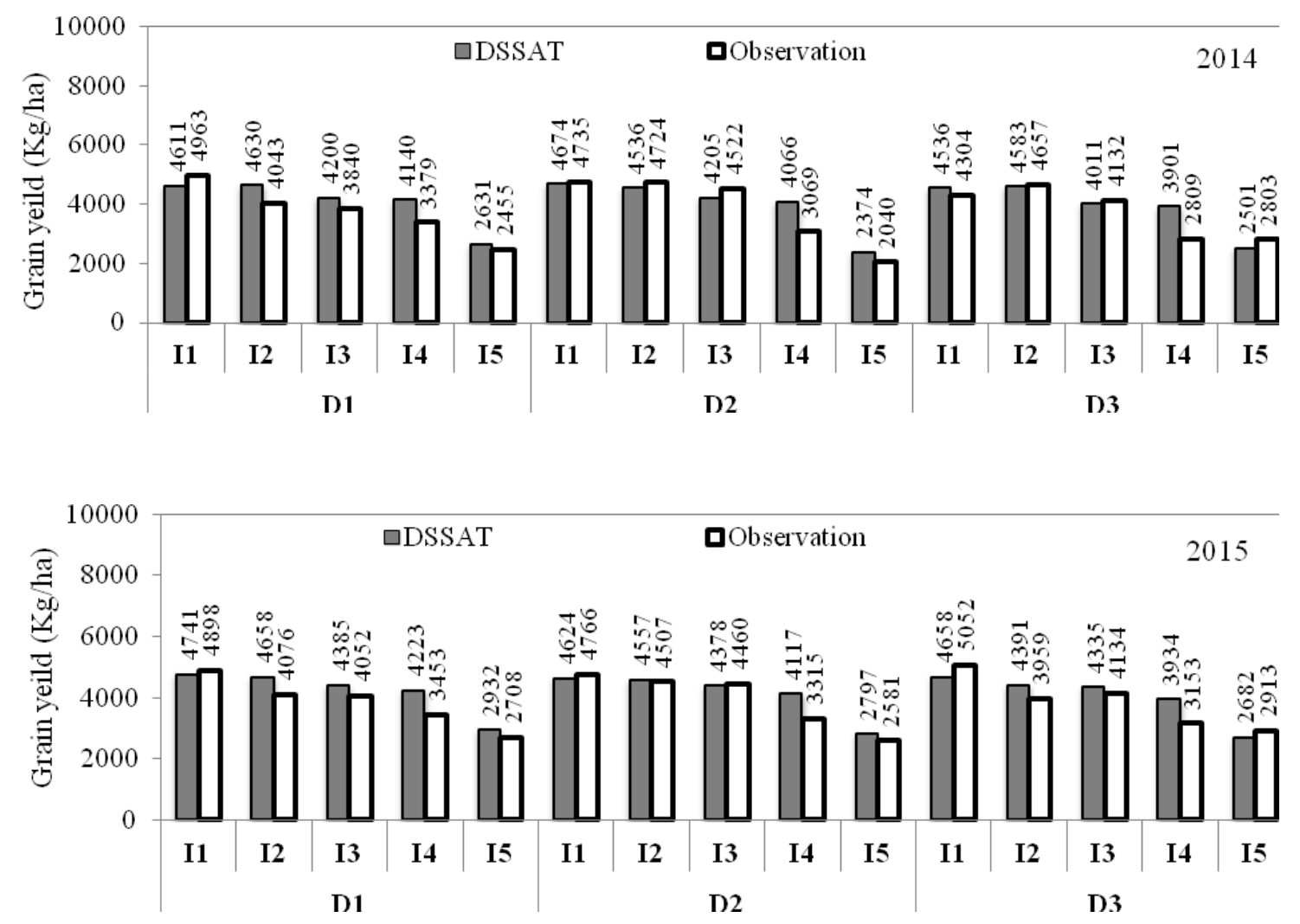

Figure 5. Performance of Ceres-Rice model for simulating grain Yield of rice under water management and plant density situations $\left(15 \times 15=D_{1}, 20 \times 20=D_{2}, 25 \times 25=D_{3} \mathrm{~cm}\right)$ 

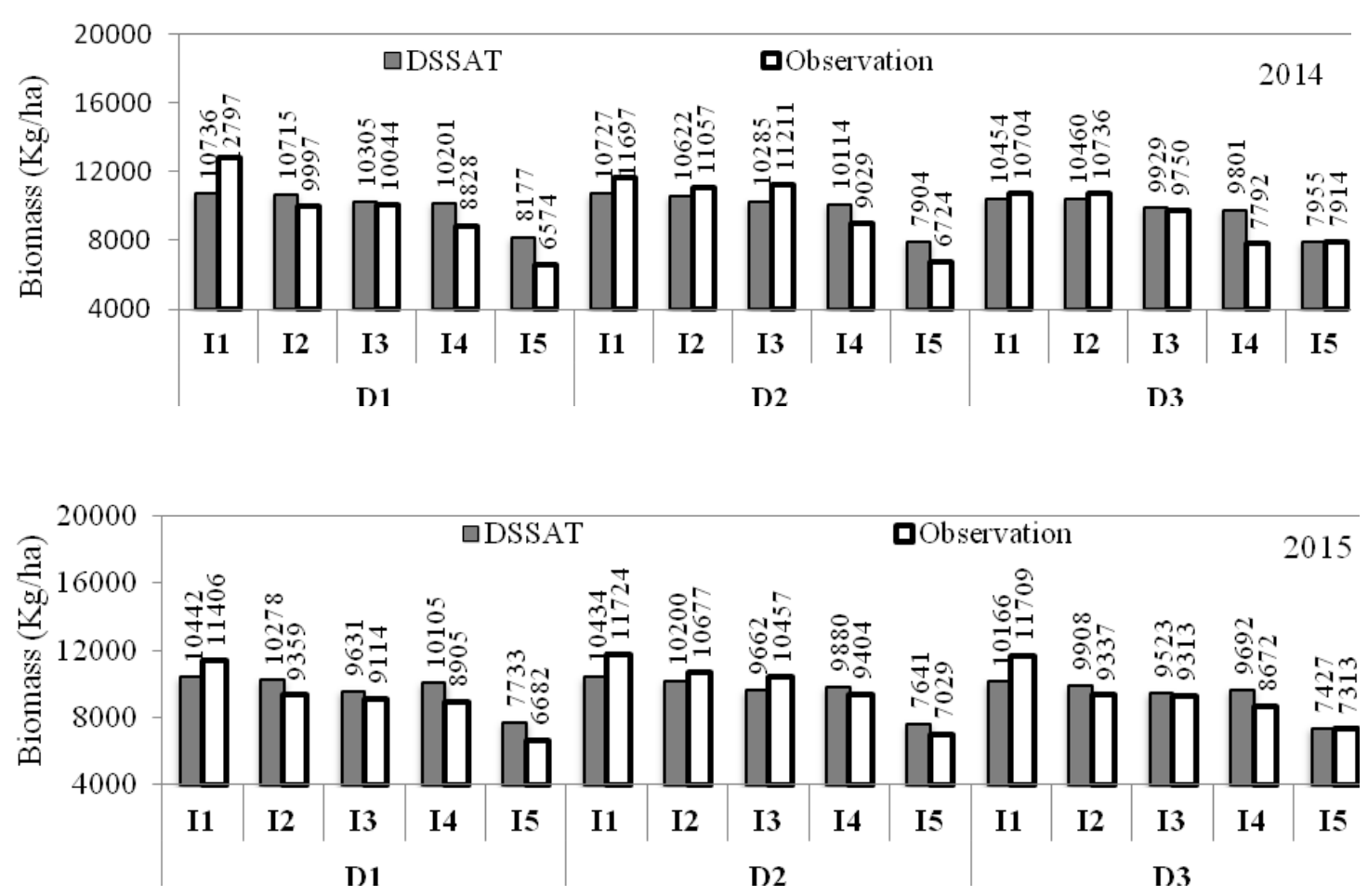

Figure 6. Performance of Ceres-Rice model for simulating Biomass of rice water management and plant density situations $\left(15 \times 15=D_{1}, 20 \times 20=D_{2}, 25 \times 25=D_{3} \mathrm{~cm}\right)$

\section{Water balance components}

An examination of simulated components of water balance under different density and water management reveals interesting facts (Fig. 7).

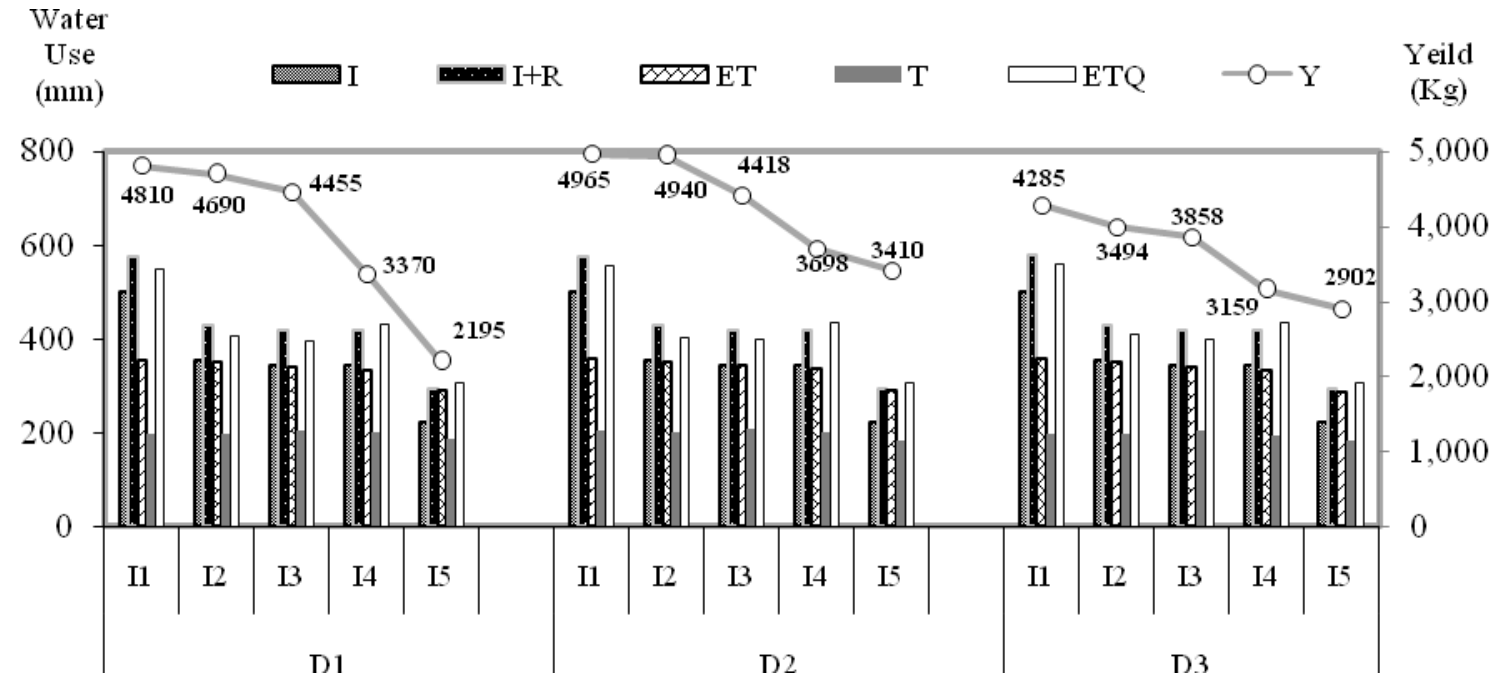

Figure 7. Water productivity values at different irrigation and crop distance treatments

The seasonal evaporation varied from 103 to $159 \mathrm{~mm}$ and showed a significant reduction with a decrease in plant spacing and applied water amount. The results of the 
model showed that the amount of evaporation (E) is 36-44\% of evapotranspiration (ET). The variability of physiological function of rice plant in irrigation management and different intervals of cultivation and changing environmental conditions leads to different transpirational requirements and consequently the amount of transpiration $(T)$ in the plant. Changing the irrigation method from floodwaters to non-floodwaters results in increased transpiration (T). Investigation of transpiration amount in irrigation management and planting distance showed that transpiration values varied in the range of $187-217 \mathrm{~mm}$; the highest transpiration $(\mathrm{T})$ was observed in $\mathrm{I}_{3}$ : Irrigation with 8 days alternative before anthesis for irrigation and crop distance $\mathrm{D}_{2}=20 \times 20 \mathrm{~cm}$ was observed at $209 \mathrm{~mm}$. Estimation of depth of penetration (ETQ) in irrigation and planting intervals showed that depth of penetration (ETQ) varies in the range of 534$295 \mathrm{~mm}$; the results of deep penetration in the study period showed that the maximum amount of water loss Through deep penetration (ETQ) was observed in flood management. Amounts of rainfall from transplanting to harvest stage were $38 \mathrm{~mm}$ for 2014 and $169 \mathrm{~mm}$ for 2015. The amount of irrigation water applied varied between $221 \mathrm{~mm}$ to $502 \mathrm{~mm}$. As the spacing increased, the depth of penetration (ETQ) increased. Irrigation with 8 days alternative before anthesis with only $4 \%$ reduction in yield (Y) compared to the usual method of flooding reduced water consumption and savings of $16 \%$ in irrigation water + precipitation $(I+R)$.

\section{Water productivity components}

The water productivity for rice was analyzed using the Ceres-Ricesimulation model. We calculated the water productivity rates using the simulated water balance components of $\mathrm{T}$ and ET by Ceres-Rice and the actual (observed) grain yield (Table 5).

Table 5. Water productivity values at different irrigation and crop distance treatments

\begin{tabular}{|c|c|c|c|c|c|c|c|c|c|c|c|}
\hline \multirow{2}{*}{\multicolumn{2}{|c|}{ Treatment }} & \multicolumn{10}{|c|}{ Year } \\
\hline & & \multicolumn{5}{|c|}{2014} & \multicolumn{5}{|c|}{2015} \\
\hline & & $\mathbf{W P}_{\mathbf{I}}$ & $\mathbf{W P}_{\mathbf{I + R}}$ & $\mathbf{W P}_{\mathbf{E T}}$ & $\mathbf{W P}_{\mathbf{T}}$ & $\mathbf{W P}_{\text {ETQ }}$ & $\mathbf{W P}_{\mathbf{I}}$ & $\mathbf{W P}_{\mathbf{I + R}}$ & $\mathbf{W P}_{\mathrm{ET}}$ & $\mathbf{W P}_{\mathbf{T}}$ & $\mathbf{W P}_{\text {ETQ }}$ \\
\hline \multirow{5}{*}{$\mathrm{D}_{1}$} & $\mathrm{I}_{1}$ & 0.92 & 0.86 & 1.30 & 2.30 & 0.86 & 0.94 & 0.77 & 1.34 & 2.40 & 0.85 \\
\hline & $\mathrm{I}_{2}$ & 1.31 & 1.19 & 1.30 & 2.33 & 1.18 & 1.32 & 1.00 & 1.36 & 2.35 & 1.12 \\
\hline & $\mathrm{I}_{3}$ & 1.22 & 1.11 & 1.20 & 1.97 & 1.09 & 1.27 & 0.96 & 1.33 & 2.22 & 1.08 \\
\hline & $\mathrm{I}_{4}$ & 1.20 & 1.09 & 1.24 & 2.08 & 0.99 & 1.23 & 0.92 & 1.26 & 2.11 & 0.95 \\
\hline & $\mathrm{I}_{5}$ & 1.19 & 1.03 & 0.90 & 1.39 & 0.89 & 1.33 & 0.87 & 1.03 & 1.59 & 0.92 \\
\hline \multirow{5}{*}{$\mathrm{D}_{2}$} & $\mathrm{I}_{1}$ & 0.93 & 0.87 & 1.28 & 2.23 & 0.85 & 0.92 & 0.75 & 1.32 & 2.32 & 0.83 \\
\hline & $\mathrm{I}_{2}$ & 1.28 & 1.17 & 1.28 & 2.26 & 1.16 & 1.29 & 0.97 & 1.32 & 2.27 & 1.09 \\
\hline & $\mathrm{I}_{3}$ & 1.22 & 1.11 & 1.19 & 1.93 & 1.08 & 1.27 & 0.96 & 1.32 & 2.19 & 1.07 \\
\hline & $\mathrm{I}_{4}$ & 1.18 & 1.08 & 1.21 & 2.01 & 0.96 & 1.20 & 0.90 & 1.23 & 2.06 & 0.93 \\
\hline & $\mathrm{I}_{5}$ & 1.07 & 0.93 & 0.81 & 1.26 & 0.81 & 1.26 & 0.83 & 0.98 & 1.53 & 0.87 \\
\hline \multirow{5}{*}{$\mathrm{D}_{3}$} & $\mathrm{I}_{1}$ & 0.90 & 0.85 & 1.25 & 2.24 & 0.83 & 0.93 & 0.76 & 1.32 & 2.39 & 0.82 \\
\hline & $\mathrm{I}_{2}$ & 1.30 & 1.18 & 1.26 & 2.27 & 1.14 & 1.24 & 0.94 & 1.29 & 2.27 & 1.05 \\
\hline & $\mathrm{I}_{3}$ & 1.17 & 1.06 & 1.14 & 1.90 & 1.03 & 1.26 & 0.95 & 1.32 & 2.18 & 1.06 \\
\hline & $\mathrm{I}_{4}$ & 1.13 & 1.03 & 1.17 & 1.99 & 0.93 & 1.14 & 0.86 & 1.19 & 2.02 & 0.88 \\
\hline & $\mathrm{I}_{5}$ & 1.13 & 0.98 & 0.86 & 1.34 & 0.85 & 1.21 & 0.80 & 0.95 & 1.50 & 0.84 \\
\hline
\end{tabular}


Table 5 shows the WP values at different irrigation and crop distance treatments in the experiment. Water productivity values for irrigation management and different densities are shown in Table 5. Water productivity is based on the amount of mechanism secretion in the plant and depends on the type of plant. As a result, $\mathrm{WP}_{\mathrm{T}}$ for a rice plant is a measurable variable that depends on eco-hydrological conditions. The results of this study indicate that the $\mathrm{WP}_{\mathrm{T}}$ value varies between 1.6 and $2.46 \mathrm{~kg} / \mathrm{cm}^{3}$. Water productivity is discussed based on the amount of evapotranspiration on soil and plant matter and shading, depending on the type of soil and climate and plant. The inevitable water shortage due to evaporation from the surface water and saturated soil (E) leads to a reduction in water productivity from $\mathrm{WP}_{\mathrm{T}}$ to $\mathrm{WP}_{\mathrm{ET}}$; on average, $\mathrm{WP}_{\mathrm{ET}}$ is $41 \%$ lower than $\mathrm{WP}_{\mathrm{T}}$. By changing the irrigation management from flood to non-waterlogging, water productivity $\left(\mathrm{WP}_{\mathrm{I}}\right)$ increases, so that the lowest water productivity $\left(\mathrm{WP}_{\mathrm{I}}\right)$ in flood treatment is $\mathrm{I}_{1}=0.92 \mathrm{~kg} / \mathrm{m}^{3}$ and The highest water productivity $\left(\mathrm{WP}_{\mathrm{I}}\right)$ was observed in saturated treatment of $\mathrm{I}_{2}=1.27 \mathrm{~kg} / \mathrm{m}^{3}$. The average amount of water-based components of irrigation, evapotranspiration, transpiration and total evapotranspiration and deep penetration $\left(\mathrm{WP}_{\mathrm{I}}, \mathrm{WP}_{\mathrm{I}+\mathrm{R}}, \mathrm{WP}_{\mathrm{ET}}, \mathrm{WP}_{\mathrm{T}}\right.$ and $\left.\mathrm{WP}_{\mathrm{ETQ}}\right)$ were $1.13,0.94,16.1,1.97$ and $0.49 \mathrm{~kg} / \mathrm{m}^{3}$ respectively. In general, $\mathrm{I}_{3} \mathrm{D}_{3}$ treatment has reduced water consumption while maintaining optimum performance and water productivity. Continuously surface water flooded method result in high soil evaporation in Hashemi rice planting. Reducing water allocation from continuous flooded methods to soil saturation or alternative irrigation methods will slightly decrease the rice yields but will substantially increase the water productivity (Amiri and Rezaei, 2013).

\section{Conclusion}

The results from this study showed that the Ceres-Rice model generally predicted biomass and grain yield, fairly satisfactorily across a range of data sets covering varying levels of water- and density management during 2 years. Results showed that predicted grain yields agreed well with observed yields $(\mathrm{RMSEa}=382$ and RMSEn $=10 \%)$. Also total biomass also were simulated well $($ RMSEa $=975$ and RMSEn $=10 \%)$. High evaporation rate at initial stages of crop growth due to traditional irrigation method, has decreased $\mathrm{WP}_{\mathrm{ET}}$ by $41 \%$ compared to $\mathrm{WP}_{\mathrm{T}}$. The results showed that $\mathrm{I}_{3}$ : Irrigation with 8 days alternative before anthesis and $\mathrm{D}_{2}=20 \times 20 \mathrm{~cm}$ plant density is the optimum irrigation method and crop density management. The Ceres-Rice model is calibrated and validated using field experimental data, and can be used to predict the experimental results of irrigation and different densities conditions in northern Iran, thus helping to identify target domains and irrigation and density management recommendations for farmers.

\section{REFERENCES}

[1] Amiri, E., Rezaei, M. (2013): Evaluation of water balance components and water productivity of rice under interval irrigation and nitrogen fertilizer conditions. - Iranian Journal of Irrigation and Drainage 4(6): 306-315.

[2] Amiri, E., Razavipour, T., Farid, A., Bannayan, M. (2011): Effects of crop density and irrigation management on water productivity of rice production in Northern Iran: field and modeling approach. - Communications in Soil Science and Plant Analysis 42(17): 20852099. 
[3] Amiri, E., Rezaei, M., Rezaei, E. E., Bannayan, M. (2014): Evaluation of Ceres-Rice, Aquacrop and Oryza2000 models in simulation of rice yield response to different irrigation and nitrogen management strategies. - Journal of Plant Nutrition 37: 1749-1769.

[4] Awan, T. H., Cruz Sta, P. C., Chauhan, B. S. (2014): Ecological significance of rice (Oryza sativa L.) planting density and nitrogen rates in managing the growth and competitive ability of itchgrass (Rottboelliacochinchinensis) in direct-seeded rice systems. - Journal of Pest Science 88(2): 427-438.

[5] Bouman, B. A. M., Kropff, M. J., Tuong, T. P., Wopereis, M. C. S., ten Berge, H. F. M., Van Laar, H. H. (2001): ORYZA2000: Modeling Lowland Rice. - International Rice Research Institute and Wageningen University and Research Centre, Los Baños, Philippines, and Wageningen, The Netherlands.

[6] Chamara, B. S., Marambe, B., Bhagirath, S. (2016): Management of Cleome rutidosperma DC. using high crop density in dry-seeded rice. - Crop Protect 95: 120-128.

[7] Chauhan, B. S., Johnson, D. E. (2011): Ecological studies on Echinochloa crus-galli and the implications for weed management in direct-seeded rice. - Crop Protect 30: 1385-1391.

[8] Clerget, B., Buenob, C., Domingob, A. J., Layaoenb, H. L., Vialb, L. (2016): Leaf emergence, tillering, plant growth, and yield in response to plant density in a high-yielding aerobic rice crop. - Field Crops Researches 199: 52-64.

[9] Davatgar, N., Neishabouri, M. R., Sepaskhah, A. R., Soltani, A. (2009): Physiological and morphological responses of rice (Oryza sativa L.) to varying water stress management strategies. - International Journal of Plant Production 3: 19-32.

[10] Gill, J. S., Walia, S. S., Gill, R. S. (2014): Direct seeded rice: An alternative rice establishment technique in north-west India - A review. - International Journal of Advanced Research 2(3): 375-386.

[11] Guan, Y. S., Serraj, R., Liu, S. H., Xu, J. L, Ali, J., Wang, W. S. (2010): Simultaneously improving yield under drought stress and non-stress conditions: a case study of rice (Oryza sativa L.). - Journal of Experimental Botany 61: 4145-4156.

[12] Hoogenboom, G., Jones, J. W., Porter, C. H., Wilkens, P. W., Boote, K. J, Batchelor, W. D, Hunt, L. A., Tsuji, G. Y. (2003): Decision Support System for Agrotechnology Transfer Version 4.0. Volume 1: Overview. - University of Hawaii, Honolulu.

[13] Murumkar, R. P., Dongarwar, U. R., Phad, D. S., Borkar, B. Y., Pisalkar, P. S. (2014): Performance testing of four row self propelled paddy transplanter. - International Journal of Science, Environment and Technology 3(6): 2015-2019.

[14] Pascual, V. J., Wang, Y. M. (2016): Utilizing rainfall and alternate wetting and drying irrigation for high water productivity in irrigated lowland paddy rice in southern Taiwan. Plant Production Science 19: 1-12.

[15] Pirdashti, H., Sarvestani, Z. T., Bahmanyar, M. A. (2009): Comparison of physiological responses among four contrast rice cultivars under drought stress conditions. - World Acad. Sci. Eng. Technol. 25: 52-53.

[16] Roderick, M., Florencia, G. R., Rodriguez, G. D. P., Lampayan, R. M., Bouman, B. A. M. (2011): Impact of the alternate wetting and drying (AWD) water-saving irrigation technique: Evidence from rice producers in the Philippines. - Food Policy 36(2): 280-288.

[17] Singh, R., Van Dam, J. C., Feddes, R. A. (2006): Water productivity analysis of irrigated crops in Sirsa district, India. - Agriculture Water Management 82: 253-278.

[18] Thakur, A. K., Mohanty, R. K., Patil, D. U., Kumar, A. (2014): Impact of water management on yield and water productivity with system of rice intensification (SRI) and conventional transplanting system in rice. - Paddy Water Environ 12: 413-424.

[19] Vijayalaxmi, G., Sreenivas, G., Leela Rani, P. (2016): Evaluation of Ceres-Rice model under various plant densities and age of seedlings in transplanted rice in Southern Telangana Zone of Telangana State. - International Journal of Current Microbiology and Applied Sciences 5(4): 667-674. 